Okajimas Fol. anat. jap., $41: 227-231,1965$

\title{
Effect of Amphetamine on Pregnancy in ICR-JCL Mice
}

\author{
By \\ Mineo Yasuda, Fumio Ariyuki and \\ Hideo Nishimura \\ Department of Anatomy, Faculty of Medicine, \\ Kyoto University, Kyoto
}

\begin{abstract}
After the thalidomide disaster, an action of psychoactive drugs on embryonal development has become the object of great interest for many teratologists, and a possible teratogenicity was tested on various sorts of such drugs in our Laboratory ( $\mathrm{T}$ a $\mathrm{k}$ a $\mathrm{n}$ o et al., 1963). Bouvet-Nitti et al. (1959) had previously demonstrated that certain drugs acting on the neurovegetative nervous system showed interference with normal pregnancy in the rat. Of this kind of drugs, amphetamine drew our special attention because of its anorexigenic action ( $\mathrm{T}$ a in ter, $1944 ; \mathrm{H}$ a r r is et al., 1947 ; R o s z k ow s k i et al., 1963), since the experiments in our Laboratory (I n a k k e et al., 1956 ; $\mathrm{N}$ is hi k a w a, 1963, 1964) showed that the reduced food intake of the pregnant mice impaired the development of their offspring.

The studies reported here deal with the effects of amphetamine sulphate on the daily food and water intake of the pregnant mice, the course of the pregnancy as well as the development of their fetuses.
\end{abstract}

\section{Materials and Methods}

Sexually matured virgin ICR-JCL mice raised in Japan Central Laboratories for Experimental Animals (Meguro, Tokyo) were caged overnight with the male mice and formation of a vaginal plug was observed; that day was considered as day 0 of pregnancy. Then, each pregnant female was caged alone and was given $50 \mathrm{mg} / \mathrm{kg}$ of amphetamine sulphate orally once daily throughout pregnancy. The drug was administered as $0.5 \%$ aqueous solution by using a gastric tube. The pregnant mice were fed OA-2 pellets made by Japan Central Laboratories for Experimental Animals and were given fresh tap water from a scaled glass tube ad libitum. Everyday around 
noon, each animal was weighed and the amount of pellets and water consumed was measured.

The animals were sacrificed at day 18.5 of pregnancy and the uterine hornes were observed. Live or dead fetuses obtained were examined externally and live ones were weighed.

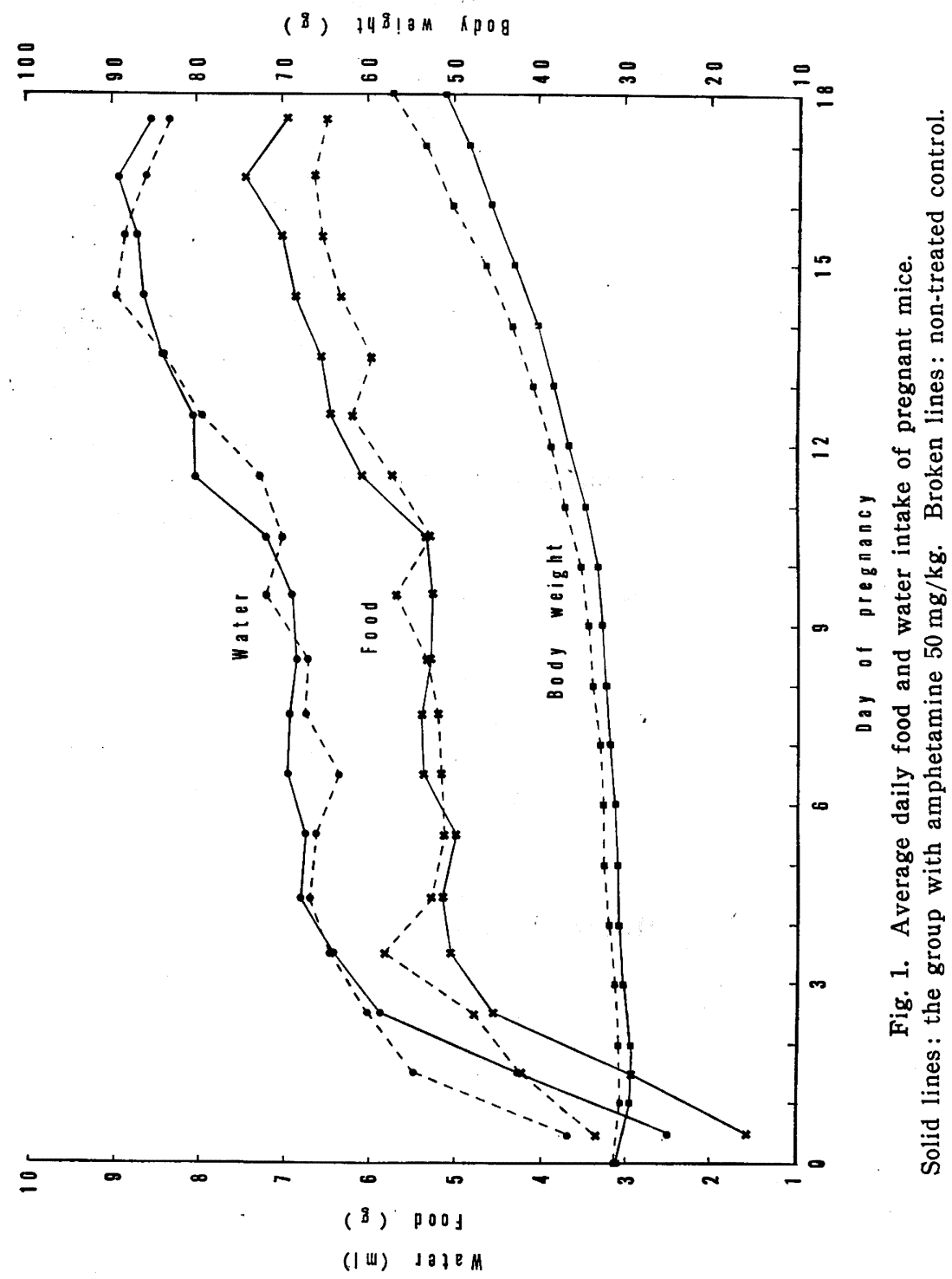


A group of non-treated pregnant mice was prepared as a control.*

\section{Results}

Within 20 minutes after the administration of amphetamine, the mice showed excitement, which continued for 6 to 7 hours. 4 out of 69 treated mice died during this period.

The daily food and water intake, and the average body weight of pregnant mice are shown in Fig. 1. It is to be noted that the amphetamine administration caused marked reduction in food and water intake only for the first two days, though the average maternal body weight of the amphetamine administered group was significantly lighter than that of the control after day 16 of gestation.

Table 1. Effect of amphetamine on the course of pregnancy

\begin{tabular}{|c|c|c|c|c|}
\hline Group & $\begin{array}{c}\text { No. of } \\
\text { copulated mice }\end{array}$ & $\begin{array}{c}\text { Not } \\
\text { implanted } \\
(\%)\end{array}$ & $\begin{array}{c}\text { Totally aborted } \\
\text { or resorbed } \\
(\%)\end{array}$ & $\begin{array}{c}\text { Gestations } \\
\text { terminated } \\
(\%)\end{array}$ \\
\hline $\begin{array}{c}\text { Amphetamine } \\
(50 \mathrm{mg} / \mathrm{kg}) \text { group }\end{array}$ & 65 & $\begin{array}{c}16 \\
(24.7)\end{array}$ & $(3.1)$ & $\begin{array}{c}47 \\
(72.2)\end{array}$ \\
\hline $\begin{array}{c}\text { Non-treated } \\
\text { Control }\end{array}$ & 26 & $\begin{array}{c}6 \\
(23.1)\end{array}$ & $\begin{array}{c}20 \\
(76.9)\end{array}$ \\
\hline
\end{tabular}

Table 2. Effect of amphetamine upon the offspring of treated mice

\begin{tabular}{|c|c|c|c|c|c|c|c|}
\hline Group & $\begin{array}{c}\text { No. of } \\
\text { mothers }\end{array}$ & $\begin{array}{c}\text { Total implants } \\
\text { (av. litter size) }\end{array}$ & $\begin{array}{c}\text { Dead } \\
(\%)^{2)}\end{array}$ & $\begin{array}{c}\text { Live } \\
(\%)^{2)}\end{array}$ & $\begin{array}{c}\text { Body weight } \\
(\mathrm{g})\end{array}$ & $\begin{array}{c}\text { Mal- } \\
\text { formed } \\
(\%)^{4)}\end{array}$ & $\begin{array}{c}\text { Type of } \\
\text { mal- } \\
\text { form.3) } \\
(\text { No. })\end{array}$ \\
\hline $\begin{array}{c}\text { Amphetamine } \\
(50 \mathrm{mg} / \mathrm{kg}) \\
\text { group }\end{array}$ & 24 & $\begin{array}{c}274 \\
(11.4 \pm 0.6)^{1)}\end{array}$ & $\begin{array}{c}48 \\
(17.5) *\end{array}$ & $\begin{array}{c}226 \\
(82.5)\end{array}$ & $1.217 \pm 0.012^{13}$ & $\begin{array}{c}6 \\
(2.7)\end{array}$ & $\begin{array}{c}\mathrm{Cp}(5) \\
\mathrm{Uh}(1)\end{array}$ \\
\hline $\begin{array}{c}\text { Non-treated } \\
\text { Control }\end{array}$ & 10 & $\begin{array}{c}127 \\
(12.7 \pm 1.0)\end{array}$ & $\begin{array}{c}12 \\
(9.5)\end{array}$ & $\begin{array}{c}115 \\
(90.5)\end{array}$ & $1.224 \pm 0.014$ & $\begin{array}{c}2 \\
(1.7)\end{array}$ & $\begin{array}{c}\mathrm{Cf}(1) \\
\mathrm{Cp}(1)\end{array}$ \\
\hline
\end{tabular}

* Statistically significant $(P<0.05)$.

1) Standard error of the mean.

2) $\%$ of total implants.

3) $\%$ of ilve fetuses.

4) Cf : Clubfoot, $\mathrm{Cp}$ : Cleft palate, Uh: Umbilical hernia.

* Another experiment was designed to determine if the procedure of intubation exerts any harmful effect: $10 \mathrm{ml} / \mathrm{kg}$ of distilled water was given by gastric intubation throughout pregnancy. It was confirmed that the pregnancy proceeded normally without increase of fetal mortality. The effect of intubation was therefore ignored in this experiment. 
It is unlikely that amphetamine caused early interruption of pregnancy (Table 1) or altered litter size (Table 2), but fetal mortality was significantly higher in the amphetamine group (Table 2). The average body weight of live fetuses in the amphetamine group was almost equal to that in the control (Table 2).

Five fetuses in the amphetamine group exhibited a cleft palate and one had an umbilical herniation, though the difference in the incidence of malformed fetuses between the amphetamine and the control graups: was statistically not significant (Table 2).

\section{Discussion}

Before this experiment, continuous administration of amphetamine was expected to reduce persistently the daily food intake of the animals; but it failed to do so after the third day of administration. Such short duration of its anorexigenic action may be due to the quickly developed tolerance to the drug as was reported by Ta inter (1944). The reduced maternal body weight in the amphetamine group might result from the high fetal mortality, or from the increased activity induced by the drug.

B ovet-Nitti et al. (1959) showed that a single intramuscular injection of $10 \mathrm{mg} / \mathrm{kg}$ of amphetamine on the 5th day post coitum failed to alter the course of pregnancy or litter size in the rat. The results of the present study are in accord with their findings, except for the high fetal mortality observed in the amphetamine group. The mechanism of the lethal action of the drug on the fetus can not be deduced from those investigations. A direct toxic action of the drug on the fetus or the stimulative action of the drug on the uterine muscle observed by $\mathrm{G} u \mathrm{n} n$ et al. (1939) might be assumed.

\section{Summary}

Amphetamine sulphate $(50 \mathrm{mg} / \mathrm{kg})$ was administered orally to the pregnant ICR-JCL mice once daily throughout pregnancy. Daily. food intake was reduced only for the first two days. However, the increase of maternal body weight during pregnancy was slightly suppressed. Amphetamine appeared not to disturb the implantation, but caused somewhat increased fetal mortality. No increase in the incidence of malformations was observed. 


\section{Acknowledgement}

This investigation was supported by NIH grant HD 00074-01. The authors gratefully acknowledge the offer of amphetamine sulphate by Takeda Chemical Industries, Ltd. (Osaka).

\section{References}

1) Bovet-Nitti, F. and Bovet, D. 1959. Action of some sympatholytic agents on pregnancy in the rat. Proc. Soc. Exp. Biol: Med., 100: 555-557.

2) Gu n n, J. A., Gurd, M.R. and Sach s, I. 1939. The action of some amines related to adrenaline: Methoxy-phenylisopropylamines. J. Physiol., 95 : 485-500.

3) Harris, S. C., I vy, A.C. and Se a r le, L. M. 1947. The mechanism of amphetamine-induced loss of weight. J.A. M. A., 134 : 1468-1475.

4) I nakake, Y. and Taka ga ki, S. 1956. The effects of various diet deficiencies upon pregnant mice and their resultant progeny. Acta Anat. Nippon., $31: 303$ 311. (Japanese)

5) $\mathrm{Nishikawa}$ M. 1963. Influence of maternal fasting for a short period upon the development of mouse embryos. Acta Anat. Nippon., 38: 181-184. (Japanese).

6) 1964. Influence of maternal fasting for a short period upon the development of mouse embryos. Acta Anat. Nippon., 39: 1-3. (Japanese)

7) Roszkowski, A.P. and Kelley, N.M. 1963. A rapid method for assessing drug inhibition of feeding behaviour. J. Pharmacol. Exp. Ther., 140: 367-374.

8) Tainter, M.L. 1944. Actions of bensedrine and propadrine in the control of obesity. J. Nutrition, $27: 89-105$.

9) Takano, K., Tanimura, T. and Nishimura, H. 1963. Effect of some psychoactive drugs administered to pregnant mice upon the development of their offspring. Proc. Cong. Anom. Res. Assoc. Jap., 3: 2-3. 